\title{
STUdy OF 1.26 Kw - 24 VdC PROTON ExCHANGE Membrane Fuel Cell's (PemfC's) Parameters OUTPUT BEHAVIOR : COMPOSITION \& TEMPERATURE
}

\author{
Md. Siddikur Rahman ${ }^{1}$, Shuva Paul ${ }^{2}$ and Ridown Rashid Riadh ${ }^{2}$ \\ ${ }^{1,2}$ Department of Electrical and Electronic Engineering, American International \\ University-Bangladesh, Dhaka, Bangladesh \\ ${ }^{2}$ Department of Electrical and Electronic Engineering, Uttara University, Dhaka, \\ Bangladesh
}

\begin{abstract}
The eternally intensifying exigency for electrical energy and the mount in the electricity expenditures due to the recent transience of the oil charges over and above to the desensitizing of the air standard resulting from the ejections of the obtaining energy transmutation devices have amplified exploration into substitute renewable proveniences of electrical energy. In today, there are six antithetical types of fuel cell technologies attainable - molten carbonate fuel cells; phosphoric acid fuel cells; solid oxide fuel cells; alkaline fuel cells; polymer electrolyte membrane fuel cells and direct methanol-air fuel cells. Polymer electrolyte membrane (PEM) fuel cells - also known proton exchange membrane fuel cells, which are one of the uncomplicated types of fuel cell. PEMFC's output power is unpredicted on nonlinearly on its output voltage and current. The output current of a proton exchange membrane fuel cell stack relies on the load located on that particular stack. This paper presents a $1.26 \mathrm{~kW}-24 \mathrm{Vdc} P E M F C$ system and DC - DC boost converter topology used in $1.26 \mathrm{~kW}$ PEM fuel cell to fortify that the zenith obtainable output power from a PEM membrane fuel cell is distributed to a load during a power outage bridging the start-up time and to optimize the health of the fuel cell membrane stack. A $1.26 \mathrm{~kW}-24$ Vdc PEMFC system is considered in this study as well as investigate how the output behaves.
\end{abstract}

\section{KEYWORDS}

PEMFC, Fuel Composition, Oxidant Composition, System Temperature, MATLAB.

\section{INTRODUCTION}

Fuel cells are salient authorizing technology for the state's energy portfolio and have the embryonic to restructure the way to power this world, propound cleaner, more-efficient alternatives to the combustion of gasoline and other fossil fuels. Fuel cells have the embryonic to substitute the internal-combustion engine in conveyances and provide power in stationary as well as portable power appeals because they are fuel-flexible, clean and energy-efficient [1]. 
Fuel cells are classified primarily by the kind of electrolyte they employ. This ranking regulates the kind of electro-chemical responses which take place in the cell, the genre of catalysts have necessitated, the temperature span in which the cell performs, the fuel necessitated and other components. These characteristics, in turn, affect the applications for which these cells are most suitable [2].

Every types of fuel cell have some unique as well as important features to specific application; however PEMFC has some unique features over all type of fuel cell.

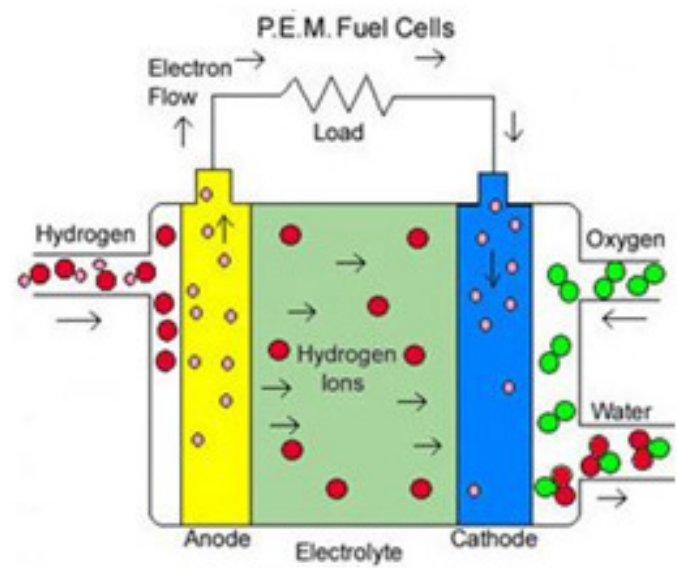

Figure 1. PEM Fuel Cell [3]

The main advantage of PEM fuel cells is their high efficiency has been compared with other energy conversion devices [4]. This enables the productivity of a fuel cell conveyance employing unswerving-hydrogen FC to be twice that in a gasoline conveyance $[5,6]$. Besides, unalike the central combustion engines where the productivity is utmost with the excessive loads, the FC productivity is also inflated with partial loads. This is preferable since in representative operating state, such as metropolitan and residential storylines, most of the conveyance is dictating a tiny snatch of the nominal FC power [7]. Therefore, an FC conveyance will be running most of the time at soaring productivity. At the aforesaid time, employing unswerving-hydrogen FC, the regional discharges issue in murky metropolitan areas can be abolished. Another significant edge of PEMFC, in dissimilarity to other types of fuel cells, is the squat action temperature (beneath $80^{\circ}$ C) [8], allowing to reach the operation point quickly. In appendage, the fetch of the substances is compacter than for the excessive temperature fuel cell (excluding the catalyst, which has been built on platinum) as well as their performance is secure. All these features revolve PEMFC particularly relevant for appeals in conveyances. Nonetheless, it is obligatory to utilize superior and more monetary, catalyst so that the rejoinder materializes at underneath temperatures.

By definition, it has been known to all, that composition means the act of combining parts or elements to form a whole. So fuel composition $[9,10]$ means the combining of hydrogen as well as oxygen but in this study percentage of hydrogen has been concerned in fuel composition. Definition of oxidant composition [9,10] is almost same as fuel composition but in this study percentage of oxygen has been concerned in oxidant composition. 
The word Temperature is clarified as the standard or strength of heat available in material or entity, especially as demonstrated according to a relative scale and appeared through a thermometer or recognized by touch. How temperature [11] changes over time has been concerned in this study.

The aim of this research is to analyse the output behavior in a comprehensive model parameterized to typify most accepted categorized of fuel cell cornucopia fortified with air and hydrogen. A Simulink model has been taken as test system to investigate the output behaviour over time. This paper is organised as follows: Section 2 presents a brief overview of fuel cell, it's working principle as well as types of fuel cell. A brief overview about basic cell structure as well as basic elements of proton exchange membrane fuel cell and it's working principle has been presented in section 3. Simulation results along with analysis have been discussed in section 4 . At the end section 5 concludes the work highlighting the major contributions.

\section{Fuel Cell \& Working Principle}

A fuel cell has been used the chemical energy of hydrogen to cleanly and efficiently produce electricity with water and heat as by-products. Fuel cells are idiosyncratic in terms of the diversity of their embryonic appeals; they have dispensed energy for structures as sizeable as an efficacy power station and as microscopic as a laptop computer.

\subsection{Fuel Cell}

In 1840, Fuel cells had been invented but have been resuscitated as an exemplary pretender for an alternative power source research. Fuel cell is an electrochemical device as well as have been generated an electric current as a result of chemical response linking between a fuel (frequently sed as hydrogen) as well as oxidant with the only ramification of the operation of being heat as well as water. Since no combustion has been taken place, efficiencies of more than two times that of a traditional IC engine are possible. A fuel cell system has been consisted of a stack of identical cells which has been combined to achieve the desired power output as well as has been shown in below. Each independent cell congregation has been consisted of an electrolyte membrane which has been sandwiched between two catalyst impregnated anode as well as cathode electrodes. This fundamental cell has further been sandwiched between two bipolar plates which have been used to deliver the reactants to the working fuel cell.

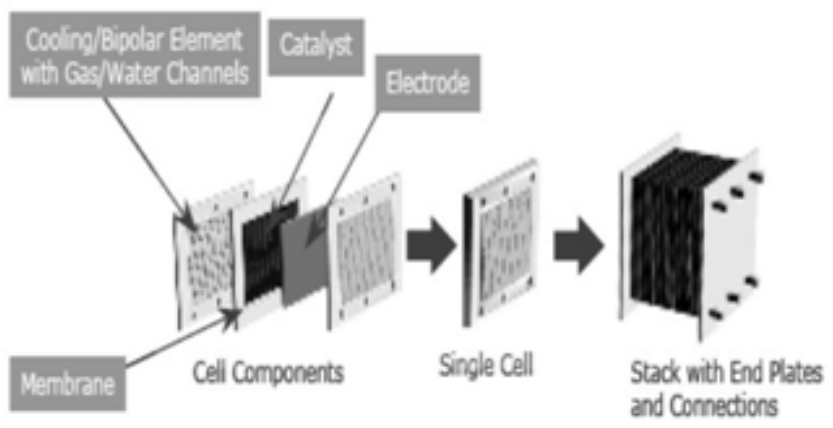

Figure 2. Components of a Fuel cell stack [12] 
Electrical \& Computer Engineering: An International Journal (ECIJ) Volume 4, Number 3, September 2015

\subsection{Working Principle of Fuel Cell}

It has been noted that the electrochemical response which has been taken place at each electrode vary according to the fuel cell type as well as consequently the electrolyte has been used. This conference will however be restricted to the most same type of fuel cell, which is the acid electrolyte hydrogen fuel cell. The working postulates of a fuel cell have been best to understand by examining a cross-section through an anode/membrane/cathode cell congregation as shown in below.

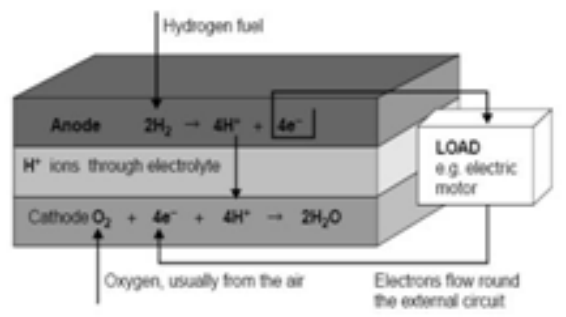

Figure 3. Electrochemical reactions of Fuel cell [13]

\subsection{Types of Fuel Cell}

Different fuel cells have been explored over time which are characterised according to the electrolyte that they use and the steering reactions. Most common fuel cells types and their application in industry are summarised below $[13,14]$.

Table 1. Summary of Different Types of Fuel Cell

\begin{tabular}{|c|c|c|c|}
\hline $\begin{array}{c}\text { Fuel Cell } \\
\text { Type }\end{array}$ & Mobile ion & $\begin{array}{c}\text { Operating } \\
\text { Temperature }\end{array}$ & Applications \& Notes \\
\hline $\begin{array}{l}\text { Proton } \\
\text { Exchange } \\
\text { Membrane } \\
\text { Fuel Cell } \\
\text { (PEMFC) } \\
\end{array}$ & $\mathrm{H}^{+}$ & $(30-100){ }^{\circ} \mathrm{C}$ & $\begin{array}{c}\text { Conveyances \& mobile appeals, } \\
\text { and for beneath power CHP } \\
\text { systems }\end{array}$ \\
\hline $\begin{array}{l}\text { Direct } \\
\text { Methanol } \\
\text { Fuel Cell } \\
\text { (DMFC) }\end{array}$ & $\mathrm{H}^{+}$ & $(20-90){ }^{\circ} \mathrm{C}$ & $\begin{array}{l}\text { Appropriate for transportable } \\
\text { electronic systems of } \\
\text { underneath power, running for } \\
\text { long-lasting }\end{array}$ \\
\hline $\begin{array}{l}\text { Phosphoric } \\
\text { Acid Fuel } \\
\text { Cell (PAFC) }\end{array}$ & $\mathrm{H}^{+}$ & $\sim 220^{\circ} \mathrm{C}$ & $\begin{array}{l}\text { Enormous numbers of } 200 \mathrm{~kW} \\
\text { CHP structures in use }\end{array}$ \\
\hline $\begin{array}{l}\text { Molten } \\
\text { Carbonate } \\
\text { Fuel Cell } \\
\text { (MCFC) } \\
\end{array}$ & $\mathrm{CO}_{3}{ }^{2-}$ & $\sim 650{ }^{\circ} \mathrm{C}$ & $\begin{array}{l}\text { Appropriate for average to large } \\
\text { scale CHP structures, up to MW } \\
\text { capacity }\end{array}$ \\
\hline $\begin{array}{l}\text { Solid Oxide } \\
\text { Fuel Cell } \\
\text { (SOFC) }\end{array}$ & $\mathrm{O}^{2-}$ & $(500-1000){ }^{\circ} \mathrm{C}$ & $\begin{array}{l}\text { Appropriate for all volumes of } \\
\text { CHP structures } 2 \mathrm{~kW} \text { to multi } \\
\text { MW }\end{array}$ \\
\hline $\begin{array}{l}\text { Alkaline Fuel } \\
\text { Cell (AFC) }\end{array}$ & $\mathrm{OH}^{-}$ & $(50-200)^{\circ} \mathrm{C}$ & $\begin{array}{c}\text { Manipulated in space } \\
\text { conveyances such as Apollo, } \\
\text { Shuttle }\end{array}$ \\
\hline
\end{tabular}


Electrical \& Computer Engineering: An International Journal (ECIJ) Volume 4, Number 3, September 2015

However, FCs have assorted conveniences over traditional combustion-root technologies as well as manipulated in passenger conveyances and in many power plants at present. They discharge no ejections at the point of performance, incorporating air pollutants and greenhouse gases which produce vapour as well as cause health issue.

\section{Proton Exchange Membrane Fuel Cell \& Working Principle}

\subsection{Proton Exchange Membrane Fuel Cell}

Proton Exchange Membrane Fuel Cells (PEMFCs) - also known as polymer electrolyte membrane fuel cells - are one of the uncomplicated kinds of fuel cell. They have been used a solid polymer (mobile proton) electrolyte which results in a reaction process the same as that for an acid electrolyte fuel cell. A solid polymer has been employed in PEM fuel cells as an electrolyte as well as penetrable carbon electrodes holding a platinum or platinum alloy catalyst [2].

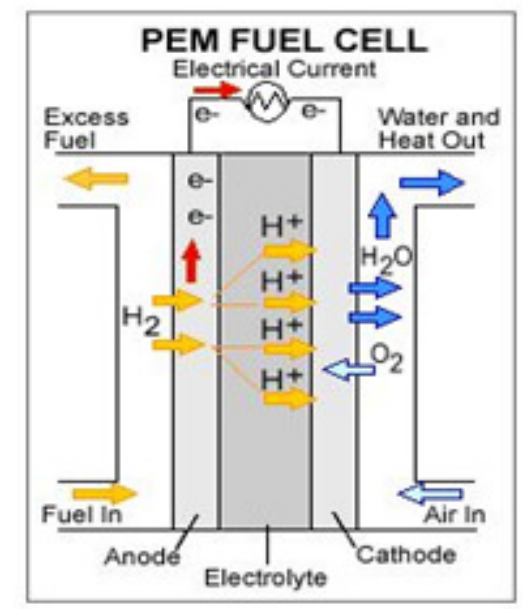

Figure 4. Schematic diagram of PEMFC [2]

PEM fuel cells have been manipulated at comparatively shallow temperatures, close to $80^{\circ} \mathrm{C}$ $\left(176^{\circ} \mathrm{F}\right)$. However, shallow temperature manipulation is permitted them to begin rapidly (below warm-up time) and consequences in rarely wear on structure constituents, appearing in better durability. Primarily, PEM fuel cells have been employed for transportation applications and some immobile applications. Because of their fast start-up time as well as approving power-toweight ratio, PEM fuel cells are especially appropriate for manipulate in passenger conveyances, like buses and cars [15].

\subsection{Basic Cell Structure of Proton Exchange Membrane of Fuel Cell}

Basically, the physical structure of a PEMFC has been consisted of seven components, according to Figure 5 [16]: catalytic layer, feeding channels, scattering layer in the anode; catalytic layer, scattering layer, membrane and feeding channels in the cathode. PEMFC has been combined in a very compact unit the electrodes and the electrolyte. This formation, known as 19 membrane electrode assembly (MEA), is not deeper that a few hundred microns and it's known as the heart 
of the fuel cell as well as has been fed with oxygen and hydrogen, promoting electrical power with a power solidity of close to $1 \mathrm{Wcm}^{-2}[17]$.

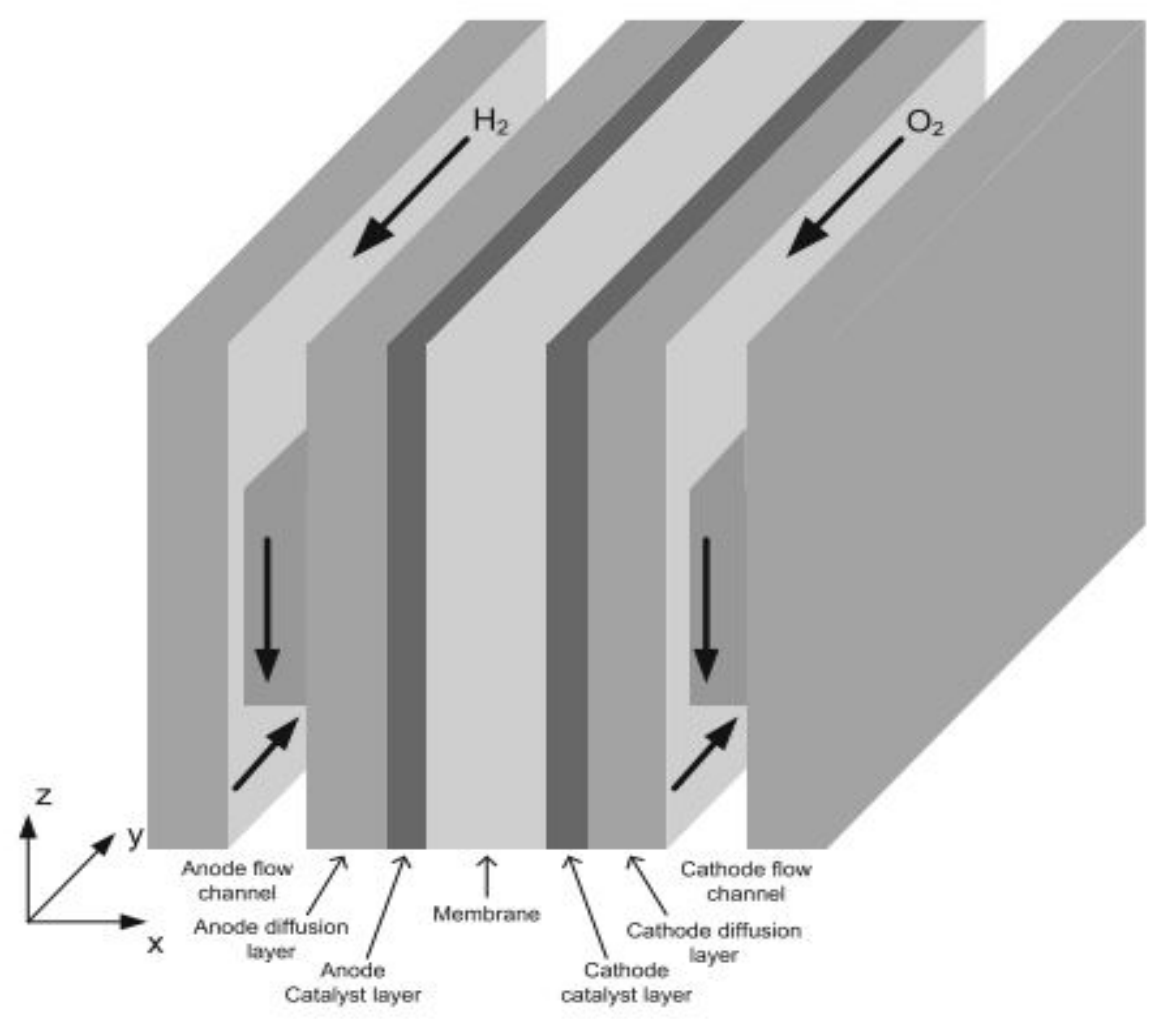

Figure 5. Schematic Diagram of Fuel Cell (3-dimensional) [16]

Polymeric solid electrode has been formed a deep electronic insulator as well as a barrier for gases in between both electrodes, permitting fast proton transport and elevated flow of electron solidity. The edge of the solid electrolyte is resisted to those of liquid type, which permits the FC to wield in any spatial position [18].The electrodes have been incorporated with a catalytic layer of great exterior area on permeable of gases, a substratum of coal. Electro catalyst materials have been obligatory to secure a better performance, increased the speed of the chemical response. In this process, gases can behave with a lower energy of activation, permitting the reaction to take place at a bottom temperature [16]. The electro catalyst has been used in PEMFC is platinum, which is one of the major drawbacks of this technology because of its high cost.

Nevertheless, there are exploration improves of lofty temperature PEM fuel cells (HT-PEMFCs) in diverse fields because there are various reasons for employing at temperatures above $100^{\circ} \mathrm{C}$ [19], such as the water management problem can be clarified because there would be no liquid water, the waste heat can be utilized manipulating cogeneration, cooling system has been clarified due to the increased temperature declivity between the coolant and the fuel cell stack, the electrochemical kinetics for the rejoinders in anode and cathode has been magnified, the tolerance to $\mathrm{CO}$ has been increased allowing the use of lower quality reformed hydrogen. Regrettably, the zone of HT-PEMFCs is emergent and still requires much research to be implemented in business appeals. 


\subsection{Basic Elements of Proton Exchange Membrane Fuel Cell}

The anode, the dissentient post of the fuel cell, has various jobs. It deportments the electrons which are discharged from the hydrogen molecules so that they can be manipulated in an external circuits. It has channels etched into it that disperse the hydrogen gas equally over the surface of the catalyst.

The cathode, the affirmative post of the fuel cell, has channels engraved into it which distribute the oxygen to the surface of the catalyst. It also conducts the electrons back from the external circuit to the catalyst, where they can recombine with the hydrogen ions and oxygen to form water [20].

$$
\begin{aligned}
& \text { Cathode }: \mathrm{O}_{2}+4 \mathrm{H}^{+} \rightarrow 2 \mathrm{H}_{2} \mathrm{O} \\
& \text { Anode }: 2 \mathrm{H}_{2} \rightarrow 4 \mathrm{H}^{+}+4 \mathrm{e}^{-} \\
& \text {Overall }: 2 \mathrm{H}_{2}+\mathrm{O}_{2} \rightarrow 2 \mathrm{H}_{2} \mathrm{O}
\end{aligned}
$$

The electrolyte is the proton exchange membrane. This exceptional served material, which glances something like standard kitchen plastic wrap, only comportment affirmatively charged ions. The membrane blocks electrons. For a proton exchange membrane fuel cell (PEMFC), the membrane should be hydrated in order to function and endure firm.

The catalyst is a special material that facilitates the reaction of oxygen and hydrogen. It is customarily made of platinum nanoparticles very narrowly coated onto carbon cloth or paper. The catalyst is bumpy and permeable so that the maximum surface region of the platinum can be exposed to the oxygen or hydrogen. The platinum-coated side of the catalyst faces the PEM [20].

\subsection{Working Principle of Proton Exchange Membrane of Fuel Cell}

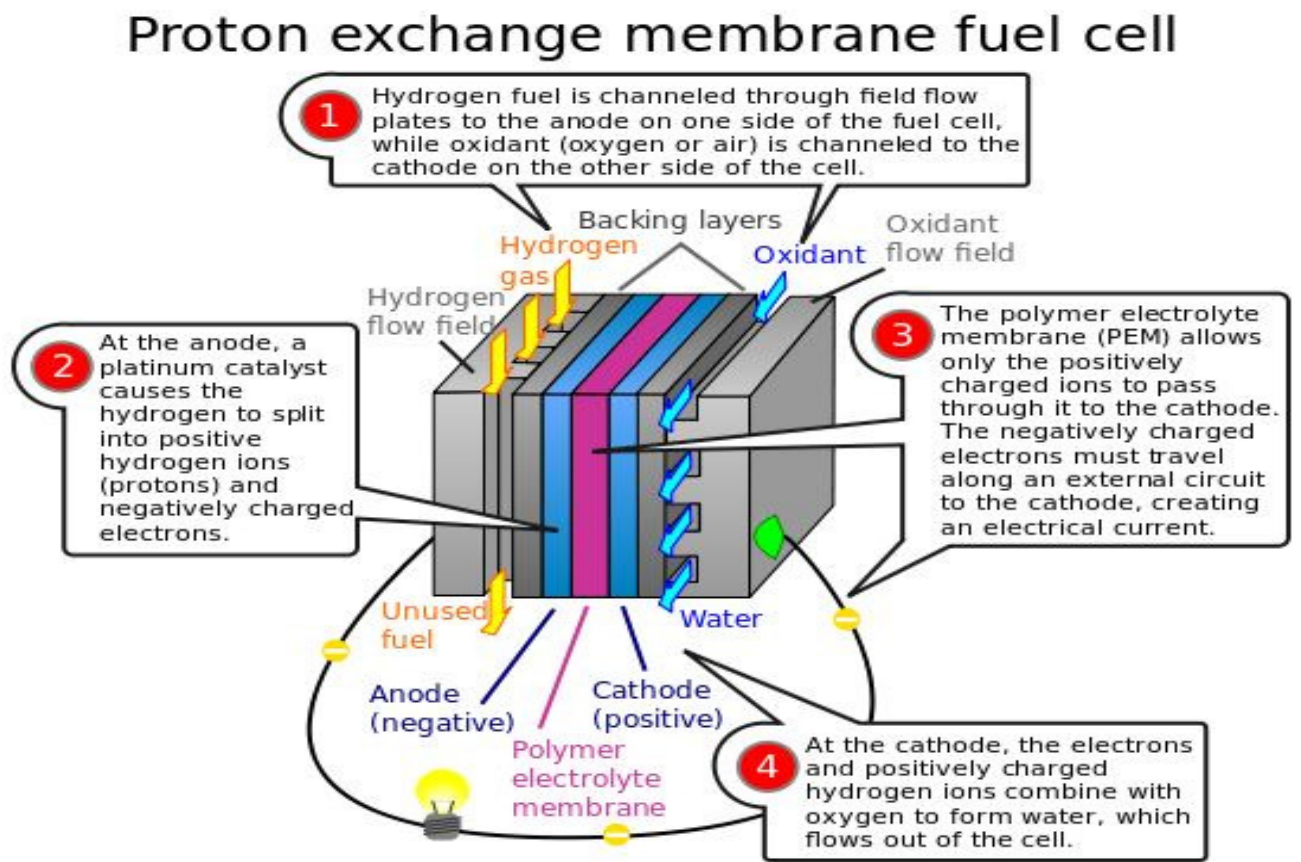

Figure 6. Working Principle representation of Proton Exchange Membrane Fuel Cell [21] 
Next section represents the simulation results carried out on a Simulink model based on fuel cell manufacturer's data sheet.

\section{TeSt System \& Simulation Result}

In this study, $1.26 \mathrm{~kW}-24 \mathrm{Vdc}$ system has been considered and the basic block diagram of this system has been shown in Figure 7 [22]. By definition, it has been known to all, that Ramp function is a unary real function, simply estimable as the mean of the independent variable as well as its absolute value. It's an input source of this test system. In this research, Boost converter (step-up converter) is a DC to DC power converter with an elevated output voltage than its input voltage. When the operating key is opened, current will be minimized as the impedance is lofty. Previously, the magnetic field is created but will be destroyed to maintain the current flow towards the load. Therefore the polarity will be back-pedaled (means sinister side of inductor will be dissentient now). As a result two sources will be in series causing a lofty voltage to charge the capacitor through the diode D. The DC input to a boost converter can be from many sources as well as batteries, like as amended AC from the mains supply, or DC from fuel cells, DC generators and dynamos. This is the reason to use Boost Converter in this study. The converter is loaded by an RL element in three systems and the value of RL element can be varied by this system's, e.g. Since the system is $1.26 \mathrm{~kW}-24 \mathrm{Vdc}$, then the value of RL element is $1.26 \mathrm{~kW}$ with a time constant 1 second.

All the results presented in this research study have been simulated with research analytical tool SimPowerSystems based in Matlab. With the help of SimPower System under SimScape division in Matlab results of output behaviour have been measured for changing input values of Ramp Function based on fuel cell stack manufacturer's data sheet [23].

\subsection{6 kW - 24 Vdc Proton Exchange Membrane Fuel Cell (PEMFC)}

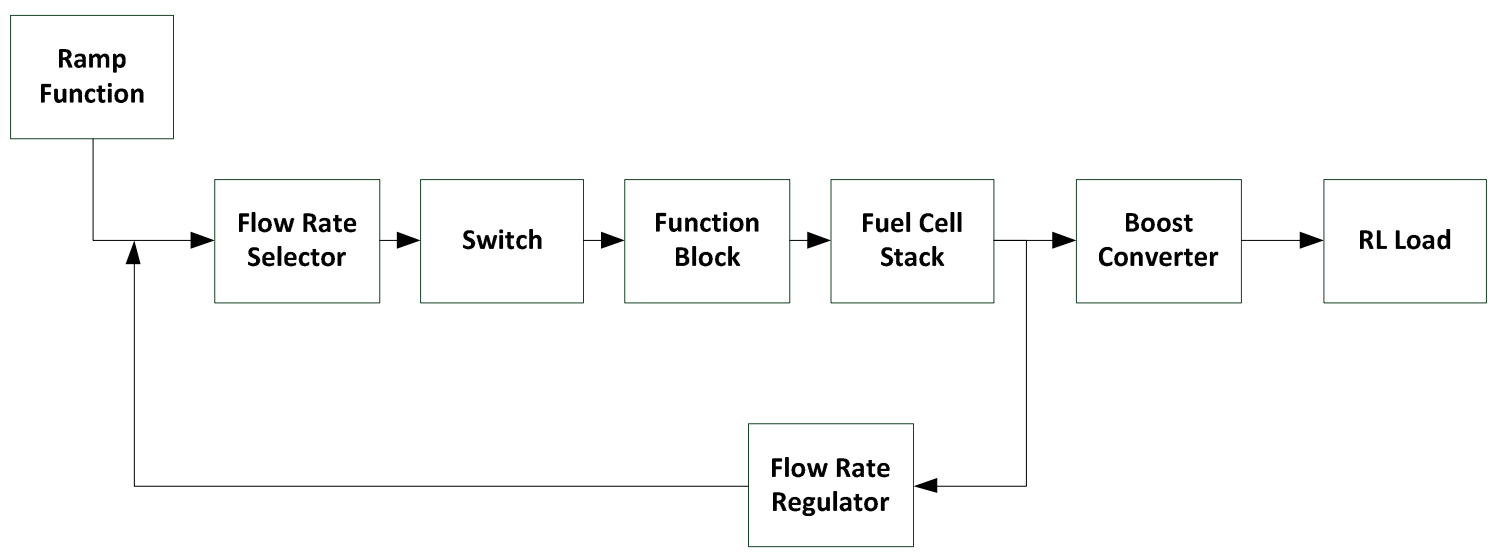

Figure 7. Block representation of $1.26 \mathrm{~kW}-24 \mathrm{Vdc}$ PEMFC system

Inside representation of Fuel Cell Stack (above Figure 7) has been presented in Figure 8 below. 
Electrical \& Computer Engineering: An International Journal (ECIJ) Volume 4, Number 3, September 2015

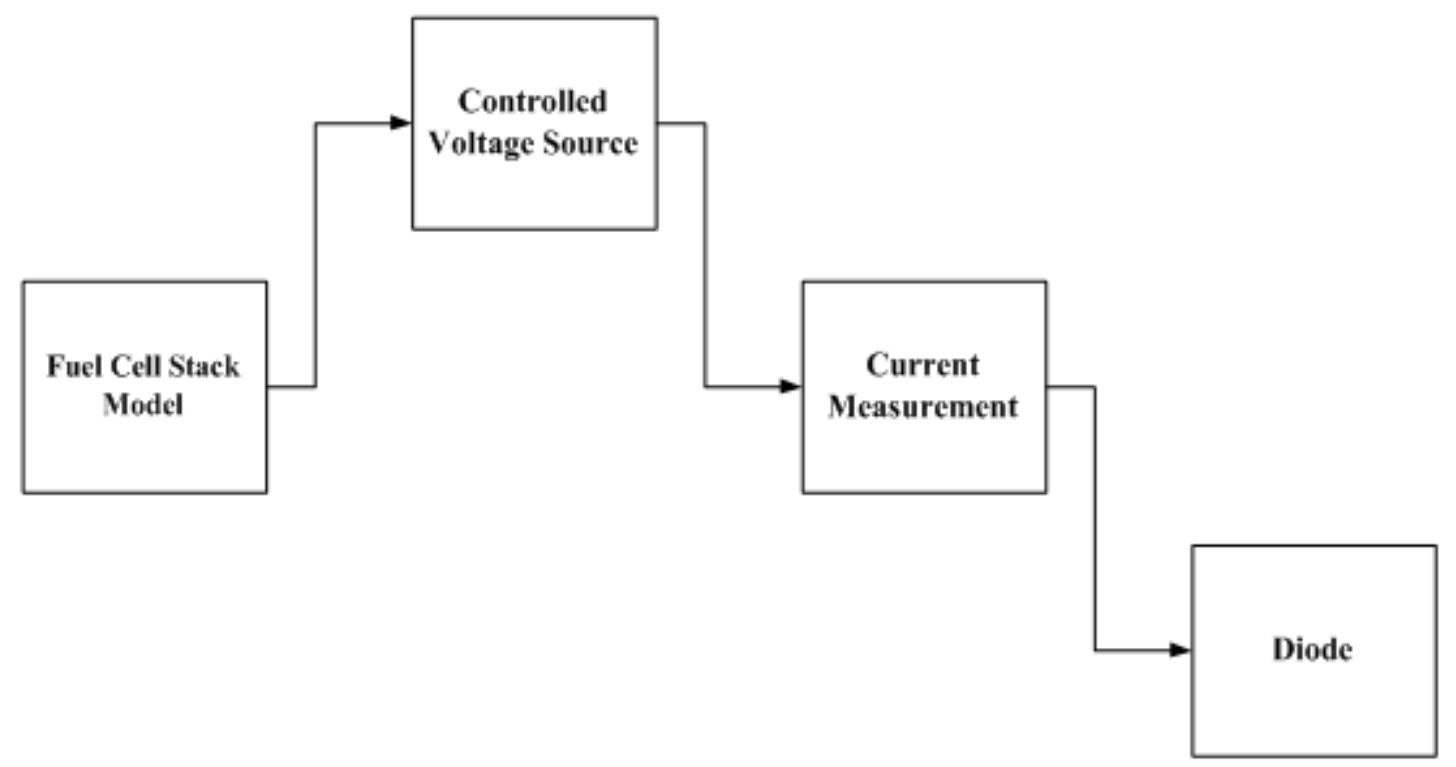

Figure 8. Block representation of Fuel cell stack (inside representation)

The prime essence which has driven the boost converter is the propensity of an inductor to endure changes in flow of electron by generating as well as wrecking a magnetic field. It has been known to all, in a boost converter, the output voltage is always higher than the input voltage. A block representation of boost converter is shown in Figure 9. Flow of electron has flown through the inductor in right handed direction when the switch has closed, and the inductor has stored some energy by initiating a magnetic field. Polarity of the sinister side of the inductor is affirmative.

\section{Boost Converter}

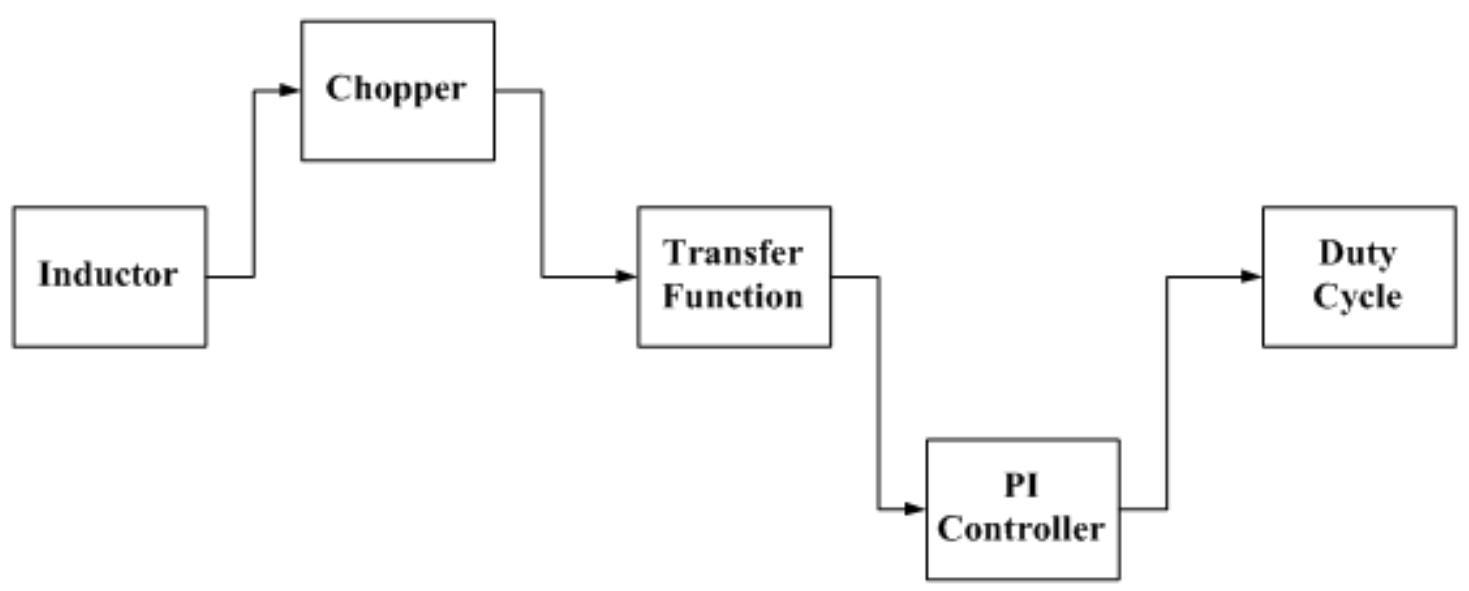

Figure 9. Block representation of Boost Converter 
Electrical \& Computer Engineering: An International Journal (ECIJ) Volume 4, Number 3, September 2015

Case Study 1: Fuel Composition of $1.26 \mathrm{~kW}-24 \mathrm{Vdc}$ PEMFC

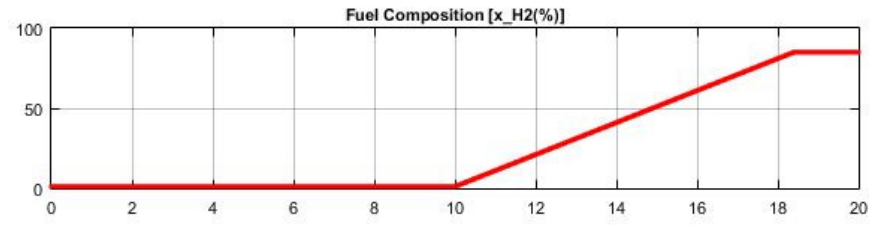

Figure 10. Fuel Composition (\%) of $1.26 \mathrm{~kW}-24 \mathrm{Vdc}$ PEMFC

Findings of Figure 10 is summarized and shown in Table II.

Table II. Measurements of Fuel Composition

\begin{tabular}{|c|c|c|}
\hline System & $\begin{array}{c}\text { Time } \\
\text { (sec.) }\end{array}$ & $\begin{array}{c}\text { Fuel Composition } \\
(\boldsymbol{\%})\end{array}$ \\
\hline \multirow{2}{*}{$\begin{array}{c}1.26 \mathrm{~kW}-24 \mathrm{Vdc} \\
\text { PEMFC }\end{array}$} & 0 & 0 \\
\cline { 2 - 3 } & 10 & 0 \\
\cline { 2 - 3 } & 20 & 85 \\
\hline
\end{tabular}

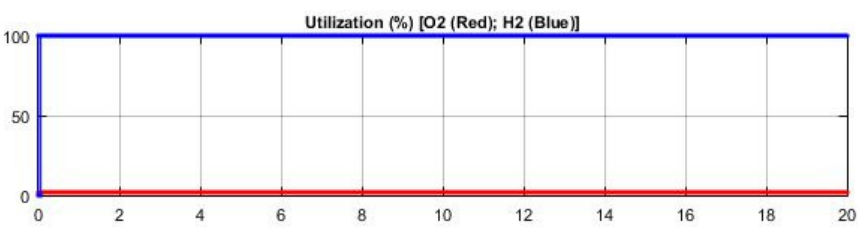

Figure 11. Utilization (\%) $\left[\mathrm{O}_{2}\right.$ (Red), $\mathrm{H}_{2}$ (Blue)] of $1.26 \mathrm{~kW}-24 \mathrm{Vdc}$ PEMFC

It's clear from Figure 11 that, the line which is marked red represents the utilization of oxygen and the line which is marked blue represents the utilization of hydrogen. The utilization of hydrogen is about $100 \%$ whereas the utilization oxygen is about $0 \%$ for entire simulation of fuel composition. It's clear from Figure 12 that, fuel consumption is about $0 \%$ for entire simulation of fuel composition. Conclude from Figure 13, stack efficiency is about $0 \%$ at 0 second and increased up to $78 \%$ at 0.7 second. After 10 second stack efficiency is increased slightly and reached $80 \%$ at 20 second.

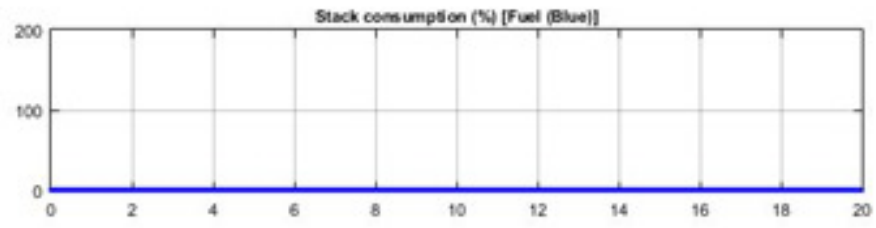

Figure 12. Stack consumption (\%) [Fuel (Blue)] of $1.26 \mathrm{~kW}-24$ Vdc PEMFC 
Electrical \& Computer Engineering: An International Journal (ECIJ) Volume 4, Number 3, September 2015

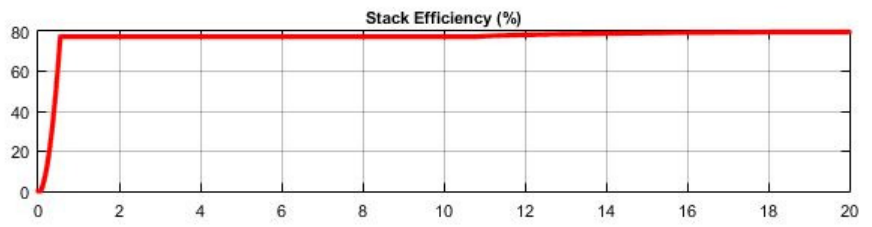

Figure 13. Stack efficiency (\%) of $1.26 \mathrm{~kW}-24 \mathrm{Vdc}$ PEMFC

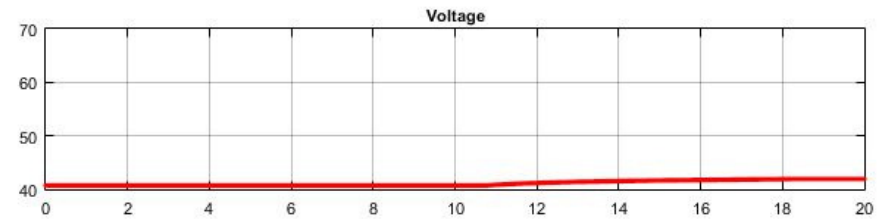

Figure 14. Fuel cell stack voltage of $1.26 \mathrm{~kW}-24 \mathrm{Vdc}$ PEMFC

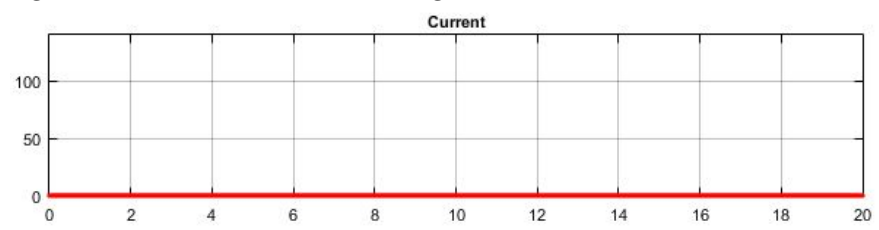

Figure 15. Fuel cell stack current of $1.26 \mathrm{~kW}-24 \mathrm{Vdc}$ PEMFC

Findings of Figure 14, 15, 16 and 17 are summarized and shown in Table III.

Table III. Important Measurements of Fuel Composition

\begin{tabular}{|c|c|c|c|c|c|}
\hline \multirow{2}{*}{ System } & Time & \multicolumn{4}{|c|}{ Fuel Composition (\%) } \\
\cline { 3 - 6 } & (sec.) & $\begin{array}{c}\text { Voltage } \\
\text { (Volts) }\end{array}$ & $\begin{array}{c}\text { Current } \\
\text { (Amp) }\end{array}$ & $\begin{array}{c}\text { DC bus } \\
\text { voltage } \\
\text { (Volts) }\end{array}$ & $\begin{array}{c}\text { DC bus } \\
\text { current } \\
\text { (Amp) }\end{array}$ \\
\hline \multirow{2}{*}{$\begin{array}{c}1.26 \mathrm{~kW}-24 \mathrm{Vdc} \\
\text { PEMFC }\end{array}$} & 0 & 40 & 0 & 100 & 0 \\
\cline { 2 - 6 } & 10 & 40 & 0 & 100 & 60 \\
\cline { 2 - 6 } & 20 & 42 & 0 & 100 & 60 \\
\hline
\end{tabular}

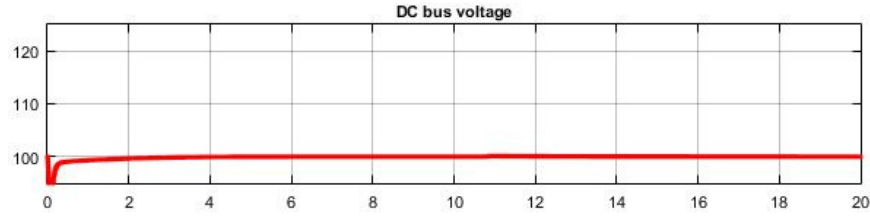

Figure 16. DC bus voltage of $1.26 \mathrm{~kW}-24 \mathrm{Vdc}$ PEMFC

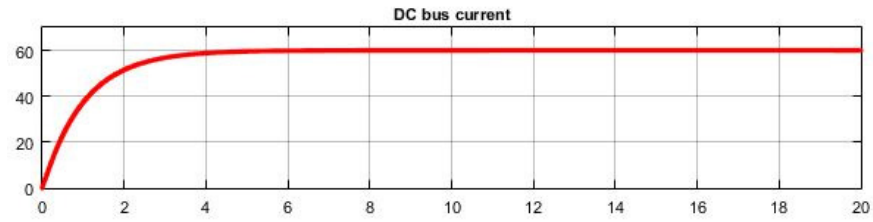

Figure 17. DC bus current of $1.26 \mathrm{~kW}-24 \mathrm{Vdc}$ PEMFC 
Electrical \& Computer Engineering: An International Journal (ECIJ) Volume 4, Number 3, September 2015

Case Study 2: Oxidant Composition of $1.26 \mathrm{~kW}-24 \mathrm{Vdc}$ PEMFC

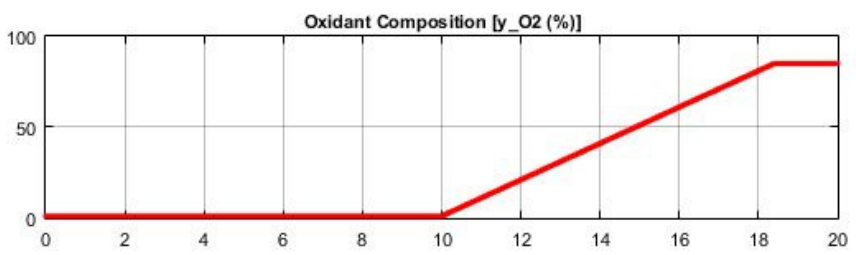

Figure 18. Oxidant Composition (\%) of $1.26 \mathrm{~kW}-24 \mathrm{Vdc}$ PEMFC

Findings of Figure 18 is summarized and shown in Table IV.

Table IV. Measurements of Oxidant Composition

\begin{tabular}{|c|c|c|}
\hline System & $\begin{array}{c}\text { Time } \\
\text { (sec.) }\end{array}$ & $\begin{array}{c}\text { Oxidant } \\
\text { Composition (\%) }\end{array}$ \\
\hline \multirow{2}{*}{$\begin{array}{c}\text { 1.26 kW - 24 Vdc } \\
\text { PEMFC }\end{array}$} & 0 & 0 \\
\cline { 2 - 3 } & 10 & 0 \\
\hline
\end{tabular}

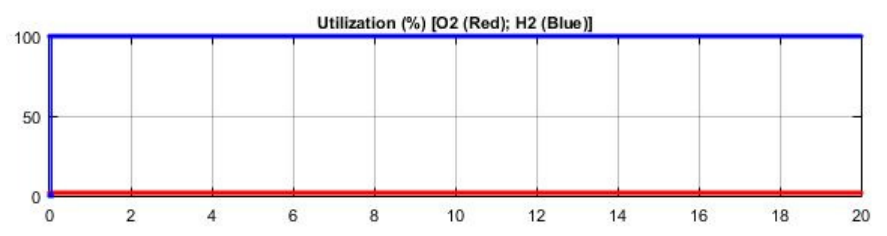

Figure 19. Utilization (\%) $\left[\mathrm{O}_{2}\right.$ (Red), $\mathrm{H}_{2}$ (Blue) $]$ of $1.26 \mathrm{~kW}-24 \mathrm{Vdc}$ PEMFC

It's clear from Figure 19 that, the line which is marked red represents the utilization of oxygen and the line which is marked blue represents the utilization of hydrogen. The utilization of hydrogen is about $100 \%$ whereas the utilization oxygen is about $0 \%$ for entire simulation of oxidant composition. It's clear from Figure 20 that, fuel consumption is about $0 \%$ for entire simulation of oxidant composition. Conclude from Figure 21, stack efficiency is about $80 \%$ at 0 second and stuck with this up to 13.5 second.

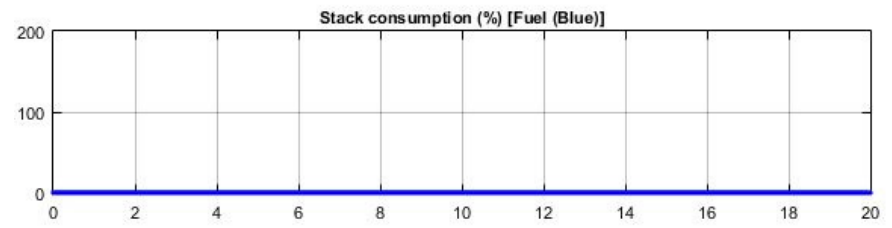

Figure 20. Stack consumption (\%) [Fuel (Blue)] of $1.26 \mathrm{~kW}-24$ Vdc PEMFC

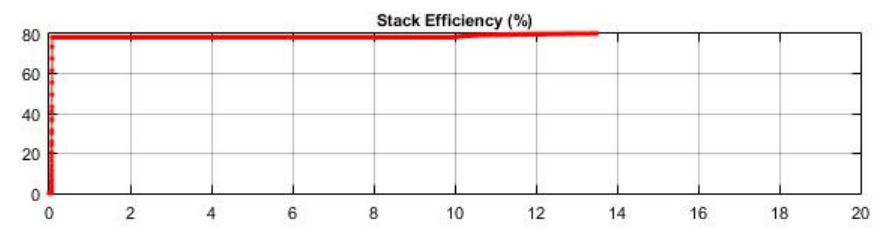

Figure 21. Stack efficiency (\%) of $1.26 \mathrm{~kW}-24 \mathrm{Vdc}$ PEMFC 
Electrical \& Computer Engineering: An International Journal (ECIJ) Volume 4, Number 3, September 2015

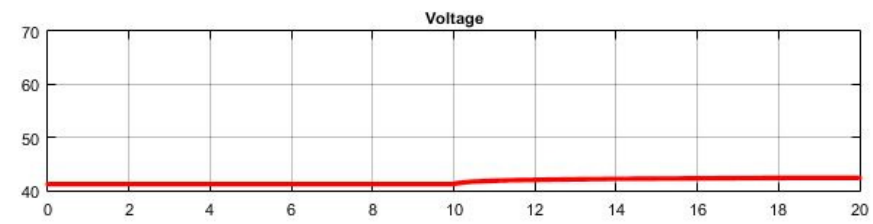

Figure 22. Fuel cell stack voltage of $1.26 \mathrm{~kW}-24 \mathrm{Vdc}$ PEMFC

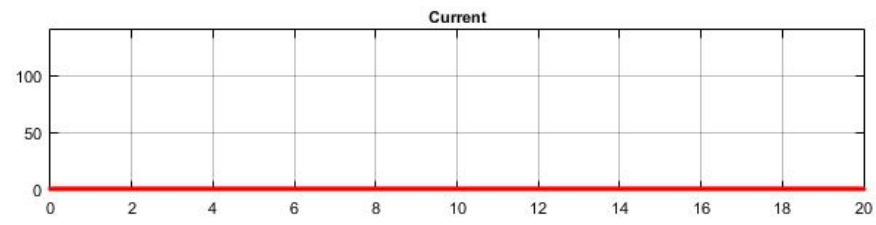

Figure 23. Fuel cell stack current of $1.26 \mathrm{~kW}-24 \mathrm{Vdc}$ PEMFC

Findings of Figure 22, 23, 24 and 25 are summarized and shown in Table V.

Table V. Important Measurements of Oxidant Composition

\begin{tabular}{|c|c|c|c|c|c|}
\hline \multirow{2}{*}{ System } & \multirow{2}{*}{$\begin{array}{c}\text { Time } \\
\text { (sec.) }\end{array}$} & $\begin{array}{c}\text { Voltage } \\
\text { (Volts) }\end{array}$ & $\begin{array}{c}\text { Current } \\
\text { (Amp) }\end{array}$ & $\begin{array}{c}\text { DC bus } \\
\text { voltage } \\
\text { (Volts) }\end{array}$ & $\begin{array}{c}\text { DC bus } \\
\text { current } \\
(\text { Amp })\end{array}$ \\
\hline \multirow{2}{*}{$\begin{array}{c}1.26 \mathrm{~kW}-24 \mathrm{Vdc} \\
\text { PEMFC }\end{array}$} & 0 & 41 & 0 & 100 & 0 \\
\cline { 2 - 6 } & 10 & 41 & 0 & 100 & 60 \\
\cline { 2 - 6 } & 20 & 43 & 0 & 100 & 60 \\
\hline
\end{tabular}

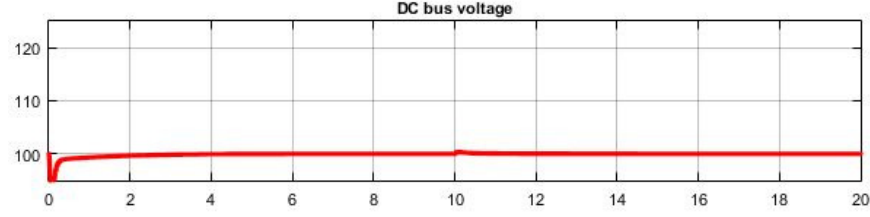

Figure 24. DC bus voltage of $1.26 \mathrm{~kW}-24 \mathrm{Vdc}$ PEMFC

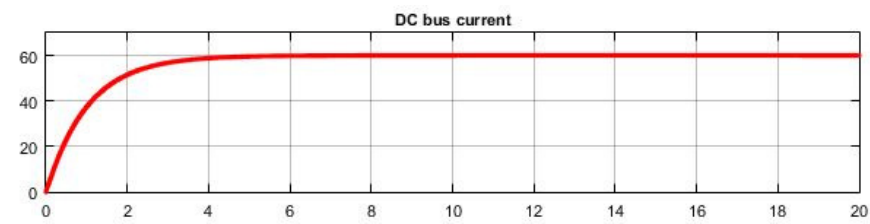

Figure 25. DC bus current of $1.26 \mathrm{~kW}-24 \mathrm{Vdc}$ PEMFC

Case Study 3: System Temperature of $1.26 \mathrm{~kW}-24 \mathrm{Vdc}$ PEMFC 
Electrical \& Computer Engineering: An International Journal (ECIJ) Volume 4, Number 3, September 2015

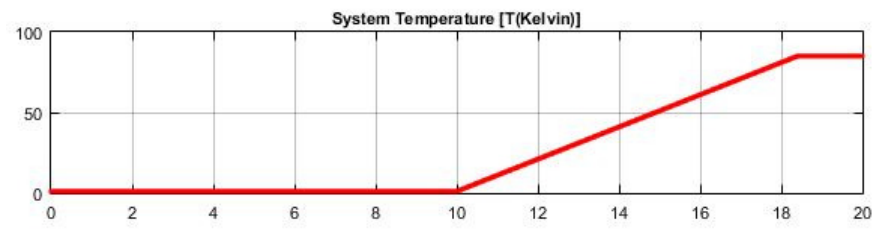

Figure 26. System Temperature (Kelvin) of $1.26 \mathrm{~kW}-24 \mathrm{Vdc}$ PEMFC

Findings of Figure 26 is summarized and shown in Table VI.

Table VI. Measurements of System Temperature

\begin{tabular}{|c|c|c|}
\hline System & $\begin{array}{c}\text { Time } \\
\text { (sec.) }\end{array}$ & $\begin{array}{c}\text { System } \\
\text { Temperature (K) }\end{array}$ \\
\hline \multirow{2}{*}{$\begin{array}{c}\text { 1.26 kW - 24 Vdc } \\
\text { PEMFC }\end{array}$} & 0 & 0 \\
\cline { 2 - 3 } & 10 & 0 \\
\cline { 2 - 3 } & 20 & 85 \\
\hline
\end{tabular}

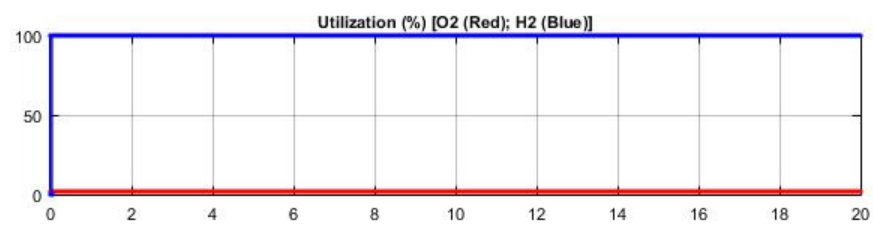

Figure 27. Utilization (\%) $\left[\mathrm{O}_{2}\right.$ (Red), $\mathrm{H}_{2}$ (Blue)] of $1.26 \mathrm{~kW}-24 \mathrm{Vdc}$ PEMFC

It's clear from Figure 27 that, the line which is marked red represents the utilization of oxygen and the line which is marked blue represents the utilization of hydrogen. The utilization of hydrogen is about $100 \%$ whereas the utilization oxygen is about $0 \%$ for entire simulation of system temperature. It's clear from Figure 28 that, fuel consumption is about $0 \%$ for entire simulation of system temperature. Conclude from Figure 29, stack efficiency is about $50 \%$ at 0 second and gradually it's decreasing.

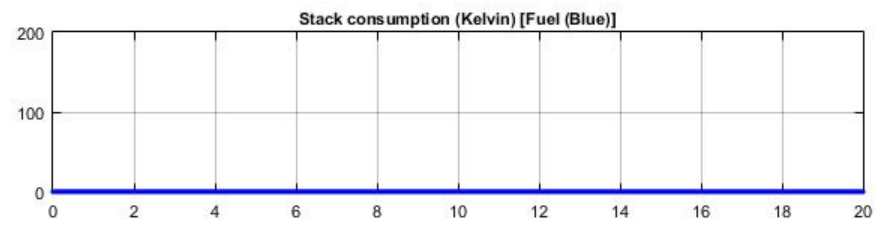

Figure 28. Stack consumption (\%) [Fuel (Blue)] of $1.26 \mathrm{~kW}-24$ Vdc PEMFC

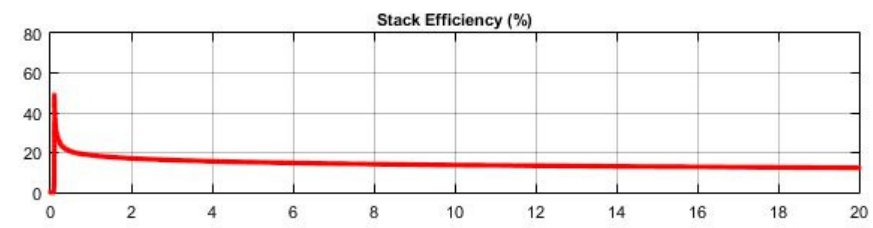

Figure 29. Stack efficiency (\%) of $1.26 \mathrm{~kW}-24 \mathrm{Vdc}$ PEMFC 
Electrical \& Computer Engineering: An International Journal (ECIJ) Volume 4, Number 3, September 2015

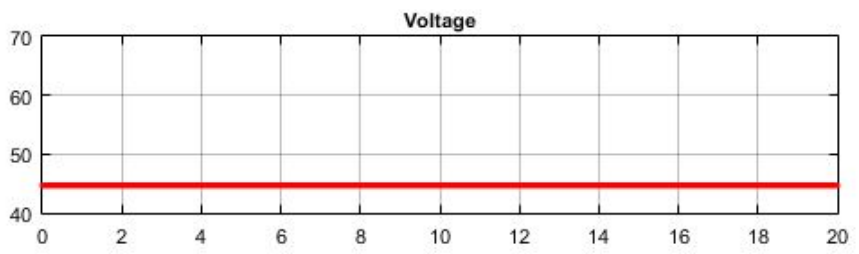

Figure 30. Fuel cell stack voltage of $1.26 \mathrm{~kW}-24 \mathrm{Vdc}$ PEMFC

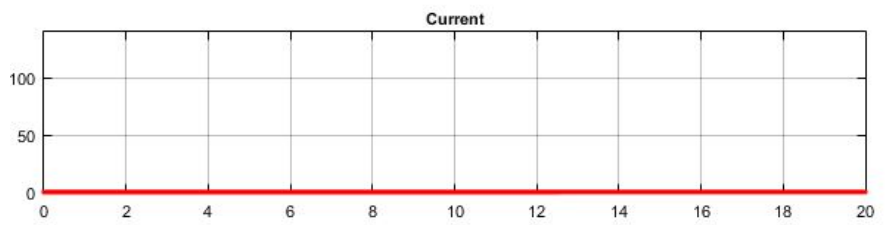

Figure 31. Fuel cell stack current of $1.26 \mathrm{~kW}-24 \mathrm{Vdc}$ PEMFC

Findings of Figure 30, 31, 32 and 33 are summarized and shown in Table VII.

Table VII. Important Measurements of System of System Temperature

\begin{tabular}{|c|c|c|c|c|c|}
\hline \multirow{2}{*}{ System } & \multirow{2}{*}{$\begin{array}{c}\text { Time } \\
\text { (sec.) }\end{array}$} & $\begin{array}{l}\text { Voltage } \\
\text { (Volts) }\end{array}$ & $\begin{array}{c}\text { Current } \\
\text { (Amp) }\end{array}$ & $\begin{array}{c}\text { DC bus } \\
\text { voltage } \\
\text { (Volts) }\end{array}$ & $\begin{array}{c}\text { DC bus } \\
\text { current } \\
\text { (Amp) }\end{array}$ \\
\hline \multirow{2}{*}{$\begin{array}{c}1.26 \mathrm{~kW}-24 \mathrm{Vdc} \\
\text { PEMFC }\end{array}$} & 0 & 45 & 0 & 100 & 0 \\
\cline { 2 - 6 } & 10 & 45 & 0 & 100 & 60 \\
\cline { 2 - 6 } & 20 & 45 & 0 & 100 & 60 \\
\hline
\end{tabular}

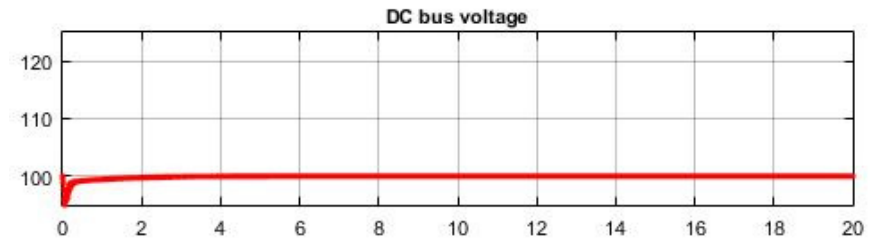

Figure 32. DC bus voltage of $1.26 \mathrm{~kW}-24 \mathrm{Vdc}$ PEMFC

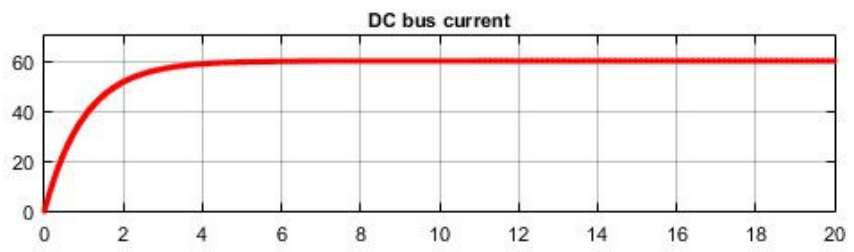

Figure 33. DC bus current of $1.26 \mathrm{~kW}-24 \mathrm{Vdc}$ PEMFC

\section{CONCLUSiOnS}

This paper has presented a study to observe the output behavior of Proton Exchange Membrane Fuel Cell's parameters. Compositions (Fuel \& Oxidant) as well as system temperature are important parameter of any type of fuel cell but these parameter are also important for Proton Exchange Membrane Fuel Cell (PEMFC) because PEMFC is used in Vehicles \& mobile 
Electrical \& Computer Engineering: An International Journal (ECIJ) Volume 4, Number 3, September 2015

applications, and for lower power CHP systems. A detail model of simulink is employed in this analysis. The results obtained good output behaviour as expected from manufacturer's data sheet. However, in future further study should be continued about the improvement of $1.26 \mathrm{~kW}-24$ Vdc PEMFC model to get better output result of these parameters such as System temperature, Fuel composition and Oxidant composition of $1.26 \mathrm{~kW}-24 \mathrm{Vdc}$ PEMFC as well as further study could be continued about $1.26 \mathrm{~kW}-24$ Vdc PEMFC taken into account of Supply pressure and Flow rate of $1.26 \mathrm{~kW}-24 \mathrm{Vdc}$ PEMFC.

\section{ACKNOWLEDGEMENTS}

The authors would like to express sincere gratitude to Mathworks (www.mathworks.com) for provide the $6 \mathrm{~kW}-45 \mathrm{Vdc}$ Fuel cell stack model of Proton Exchange Membrane Fuel Cell (PEMFC) during the preparation of this paper.

\section{REFERENCES}

[1] Fuel Cells [Online]. Available: http://energy.gov/eere/fuelcells/fuel-cells.

[2] Types of Fuel Cells [Online]. Available: http://energy.gov/eere/fuelcells/types-fuel-cells.

[3] Fuel Cell Basics [Online]. Available: http://americanhistory.si.edu/fuelcells/basics.htm.

[4] Carrette L, Friedrich K, Stimming U (2001) Fuel cells-fundamentals and applications. Fuel Cells 1(1):5-39.

[5] Rajashekara K (2000) Propulsion system strategies for fuel cell vehicles. Fuel Cell Technol for Vehicles 1:179-187.

[6] Jeong K, Oh B (2002) Fuel economic and life-cycle cost analysis of a fuel cell hybrid vehicle.J Power Sources 105:58-65.

[7] Friedman D, Moore R (1998) PEM fuel cell system optimization. In: Proc Electrochem Soc 27:407423.

[8] EG \& G Technical Services, Inc. Science Applications International Corporation (2002) IN: U.S. Department of Energy, Fuel Cell Handbook, 6th edition, Morgantown, West Virginia, USA.

[9] Chan, Kin Yip, Andrzej Ordys, Olga Duran, Konstantin Volkov, and Jiamei Deng. "Adaptive neurofuzzy method to estimate virtual SI engine fuel composition using residual gas parameters." In Control (CONTROL), 2014 UKACC International Conference on, pp. 174-179. IEEE, 2014.

[10] Benjamin, Thomas G., Elias H. Camara, and Leonard G. Marianowski.Handbook of fuel cell performance. No. COO-1545-T1. Institute of Gas Technology, Chicago, IL (USA), 1980.

[11] Yang, C., P. Costamagna, S. Srinivasan, J. Benziger, and A. B. Bocarsly. "Approaches and technical challenges to high temperature operation of proton exchange membrane fuel cells." Journal of Power Sources 103, no. 1 (2001): 1-9.

[12] Boyce, M.P. (2006), Gas turbine engineering handbook, 3rd ed., Gulf Professional Pub., Boston.

[13] Covert, E. E. (1985), Thrust and drag: its prediction and verification, American Institute of Aeronautics and Astronautics, New York.

[14] Types of Fuel Cell [Online]. Available: http://energy.gov/eere/fuelcells/types-fuel-cells.

[15] Ledjeff, K., \& Nolte, R. (1999). U.S. Patent No. 5,863,672. Washington, DC: U.S. Patent and Trademark Office.

[16] Yao K, Karan K, McAuley K, Oosthuizen P, Peppley B, Xie T (2004) A review of mathematical models for hydrogen and direct methanol polymer electrolyte membrane fuel cells. Fuel Cells 4(12):3-29.

[17] D'Arco S, Ianuzzi D, Pagano M, Tricoli P (2005) Design criteria optimizing the use of fuel cell source in electric power system. In: Proceedings of the 16th IFAC World Congress, Prague.

[18] Laughton MA (2002) Fuel cells. Power Eng J 16:37-47.

[19] Zhang J, Xie Z, Zhang J, Tang Y, Song C, Navessin T, Shi Z, Song D, Wang H, Wilkinson DP, Liu Z-S, Holdcroft S (2006) High temperature pem fuel cells. J Power Sources 160(2):872-891. 
Electrical \& Computer Engineering: An International Journal (ECIJ) Volume 4, Number 3, September 2015

[20] Proton Exchange Membrane Fuel Cell [Online]. Available: http://www.hydrogenics.com/

[21] Kakati, B. K., Deka, D., "Effect of resin matrix precursor on the properties of graphite composite bipolar plate for PEM fuel cell", Energy \& Fuels 2007, 21 (3):1681-1687.

[22] Fuel Cell Stack [Online].Available: http://www.mathworks.com/help/physmod/sps/powersys/ref/fuelcellstack.html

[23] NedStack PS6 Product Data - Fuel Cell Markets [Online]. Available: www.fuelcellmarkets.com/content/images/articles/ps6.pdf 